\title{
Papanicolaou smear in pregnant women: a prospective study
}

\author{
Niyaf NA, Bhavya HU, Ravikanth GO, Geeta J Doppa \\ Corresponding author: Dr. Bhavya HU, Associate Professor, Dept of Obstetrics \& Gynecology, KVG \\ Medical college \& Hospital, Sullia, Karnataka, India; Email : bhavyahu.obg@gmail.com
}

Distributed under Attribution-Non Commercial - Share Alike 4.0 International (CC BY-NC-SA 4.0)

\section{ABSTRACT}

\begin{abstract}
Objectives: Aim of the study is to assess the prevalence of abnormal pap smear in pregnant women and its associated risk factors. Methods: This is a prospective observational study, 200 pregnant women were recruited who came for regular antenatal visit. Papanicolaou smear was done as per conventional method and reported using 2014 Bethesda system. Results: $53.6 \%$ of pregnant women had abnormal pap smear. Among them, 29\% had inflammatory smears, $9 \%$ had bacterial vaginosis, 3\% showed trichomonal and 7\% monilialiasis. The abnormal smears were more in patients from rural background (58.5\%) than urban (29\%), which is statistically significant. Most of them in lower class $(88.8 \%$ ) had abnormal pap. The frequency of abnormal pap in illiterates was $83.3 \%, 64.7 \%$ in middle school, in senior secondary it was $50.7 \%$ and graduates was $37.83 \%$. There were $86.5 \%$ abnormal smears in those $<21$ years of age at first intercourse as compared to $33.06 \%$ in those $\geq 21$ years of age and the difference was statistically significant. There were $4(80 \%)$ abnormal smears among those with more than one sexual partner as compared to $1(20 \%)$ normal smear. $26(30.58 \%)$ abnormal smears in primigravida and $74(67.88 \%)$ abnormal smears in multigravida was noted which was statistically significant. Conclusion: Clinicians should make every effort to educate, counsel and screen pregnant women if they have not had a pap test in the past in order to reduce the burden of cervical cancer in our country. This opportunity for screening cervical cancer should not be missed in the antenatal period.
\end{abstract}

Keywords: Risk factors, abnormal pap, cervical cancer screening, pregnancy.

Cervical cancer is the commonest cancer and leading cause of death among women in developing countries. ${ }^{1}$ It is the fourth most common cancer among women globally, with an estimated 570,000 new cases in 2018. ${ }^{2}$ Cervical cancer is the second most common cancer in India, accounting for $22.86 \%$ of all cancer cases in women and is the third largest cause of cancer mortality accounting for nearly $10 \%$ of all cancer related deaths in the country. ${ }^{3,4}$ It is an important public health problem for women leading to annual mortality of 70,000 and India has the largest burden of cervical cancer patients in the world. ${ }^{5,6}$ The relative five year survival averages to $69 \%$ and the length of survival depends on the cancer stage at the time of detection. ${ }^{7}$ The survival chance of a person becomes better if the cervical cancer is detected and treated at earlier stages. Therefore, it is important to avail of cervical cancer screening.
The introduction of cytology screening by Dr. George Nicholas Papanicolaou during 1940s was a great public health success in cervical cancer prevention as it detects potentially pre-cancerous and cancerous lesions in the cervix. ${ }^{8}$ Since the introduction of the conventional cytology or pap smear, the incidence and mortality of cervical cancer has dramatically decreased in many developed countries. ${ }^{9}$ Abnormalities in cervical cytology are found in up to $5 \%$ of all pregnancies. Risk of invasive carcinoma ranges between $1-10 / 10,000$ pregnancies. ${ }^{10}$ In western countries, cytological screening is a standard part of antenatal protocols, but no such screening program exists in India.

The peak age of incidence of pre-cancerous lesions of the cervix is between $25-35$ years of age. ${ }^{11}$ Antenatal period is a time when women come voluntarily to seek health care for pregnancy. This opportunity should be utilized to down stage

Received: $5^{\text {th }}$ February 2021, Peer review completed: $10^{\text {th }}$ April 2021, Accepted: $1^{\text {st }}$ May 2021.

Niyaf NA, Bhavya HU, Ravikanth GO, Doppa GJ. Papanicolaou smear in pregnant women: a prospective study. The New Indian Journal of OBGYN. 2022; 8(2): 220 - 26. 
cancer cervix by detection of pre-invasive lesions with cytology who otherwise might not report for screening. Pap test detects $60-70 \%$ of cancer cervix. The accuracy of pap smear in pregnancy is almost similar to that of non-pregnant women.

Most of the reproductive tract infections are asymptomatic making their detection and diagnosis difficult. During pregnancy, the symptoms of vulvo-vaginitis depend on clinical, behavioral and demographic factors. ${ }^{12}$ Pap smear can also detect vaginal infections. The 3 most common causes of vaginal infections are bacterial vaginosis, followed by candidiasis and trichomoniasis ${ }^{13}$. These can cause various types of morbidity in women particularly during pregnancy resulting in abortion, preterm labour and stillbirth. ${ }^{14,}{ }^{15}$ Vaginal infections can lead to many complications; it is of the prime importance to know the causative organisms, prevalence and its attributing factors affecting the pregnant women.

Numerous studies have shown an association between certain risk factors, dysplasia and cervical cancer which include gravidity, contraceptive use, age of first coitus, multiple partners, coexisting microbial infections, altered immune status, smoking and oral contraceptive use. In Indian setup, data on abnormal pap smear in pregnancy is lacking. The present study was designed to know the prevalence of abnormal pap smear and its associated risk factors in pregnancy.

\section{Methods}

It is a prospective observational study conducted from 2018 to 2020 at tertiary care centre, Dakshina Kannada Karnataka, India. The study was approved by the institutional ethics committee. Considering the prevalence of $8 \%$ of abnormal smear in pregnancy and $4 \%$ allowable error at $95 \%$ confidence level and $5 \%$ of level of significance, the sample size was calculated to be $200 .{ }^{16}$ Hence, 200 pregnant women were enrolled in the study who fulfilled the criteria mentioned below.

Inclusion criteria: All pregnant women who will come for regular antenatal check up.

Exclusion criteria:

$>$ Women with history of threatened abortion in present pregnancy.

$>$ Pregnant women not willing for pap smear.

$>$ History of intercourse, vaginal examination, vaginal medication in the past 48 hours.

$>$ Bleeding per vagina.

$>$ Preterm premature rupture of membranes, preterm labor or obvious cervical dilatation on speculum examination.
Informed written consent was obtained from all the study subjects. A proforma containing general information on maternal age, parity, age at marriage, education, occupation, residence, socioeconomic status, contraception, sexual partners, smoking history and family history regarding cervical cancer was taken. Those with abnormal pap tests were managed as per protocol.

After emptying the bladder, patient was put in dorsal position. After exposing the cervix using Cusco's self retaining speculum or Sim's bivalve speculum with an anterior vaginal wall retractor, speculum findings were noted, ectocervix was sampled using an Ayer's spatula by rotating 360 degrees and then smearing on glass slides. It was immediately fixed with $95 \%$ ethyl alcohol, stained with papanicolaou stain and results were reported according to modified Bethesda classification 2014.

Statistical analysis: Descriptive statistics, the data was entered in Microsoft excel 2019 and all statistical data was analysed using statistical package for social sciences 11.0. Frequency, percentages and ratios were analysed from the data and the results were displayed in tables. Chi square test and $t$ test was used to assess the statistical significance of the findings. Statistical significance was determined at $\mathrm{p}<0.05$.

\section{Results}

A total of 200 pregnant women were included in the study and results were analysed. Out of the 200 smears that were taken in our study, 6/200 (3\%) of them were inadequate and the remaining 194 smears were adequate with a percentage of $97 \%$ smear adequacy as shown in figure 1.

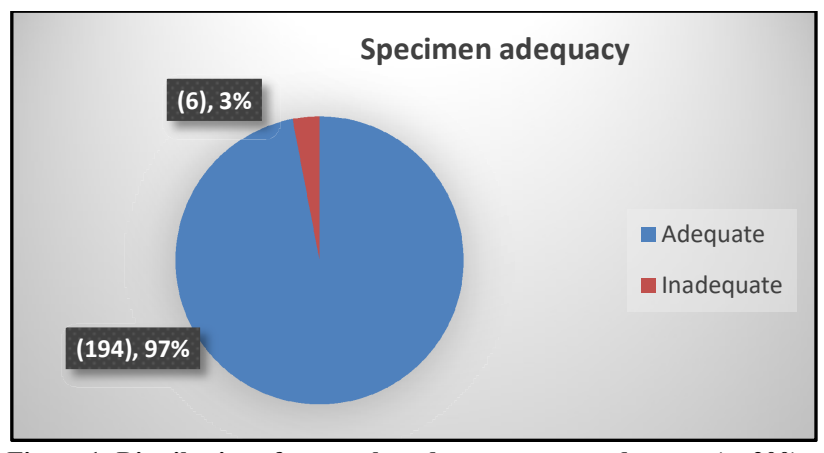

Figure 1: Distribution of smears based on pap smear adequacy $(\mathrm{n}=\mathbf{2 0 0})$

The Pap smear results revealed that out of 194, 100 $(51.55 \%)$ of them had abnormal findings and the remaining $94(48.45 \%)$ were negative for intra-epithelial malignancy. Among the abnormal smears, 58 (29\%) women had inflammatory smears, $18(9 \%)$ had bacterial vaginosis while $14(7 \%)$ and $6(3.34 \%)$ had monilial and trichomonal 
pathology, only $1.03 \%$ were low grade squamous intra epithelial lesion (LSIL) and atypical squamous cells of undetermined significance (ASCUS) each respectively (figure 2).

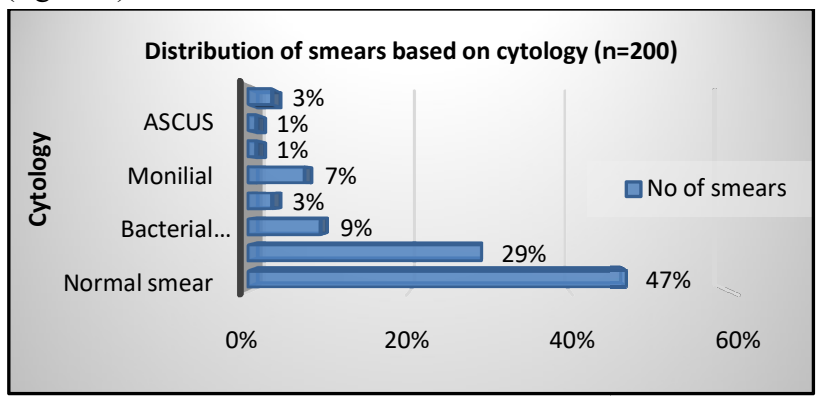

Figure 2: Distribution of smears based on cytology $(\mathrm{n}=\mathbf{2 0 0})$

In our study it was seen that more than half of the participants belonged to the age group between 20 to 30 years in both the groups, there was no much difference in age distribution. The mean age of the participants with normal Pap smear was 27.24 \pm 4.49 years and that of abnormal pap smear was $26.81 \pm 4.48$ years, hence the difference between the ages of women in the normal and abnormal pap smear groups is not statistically significant (table 1).

According to residence, there were 147 subjects from rural background and 47 subjects from urban background. There were $86(58.50 \%)$ from rural and 14 (29.78\%) from
As shown in table 1, all the subjects were classified according to the modified Kuppuswamy socioeconomic status scale (2016). In our study, majority of the participants were from lower middle class i.e., 78 (51.65\%), followed by upper middle class $(9.80 \%)$, upper lower $(7.7 \%)$ and lastly lower class (4.63\%). Most of the participants in the lower class $(88.8 \%)$ had abnormal pap smears. The odds of having an abnormal pap smear was more in lower middle, upper lower and lower class and the difference was statistically significant with $\mathrm{p}$ value less than 0.05 .

The frequency of abnormal pap smear in illiterate population was $10(83.33 \%), 11(64.70 \%)$ in middle school educated women, in senior secondary it was $65(50.7 \%)$ and in graduates was $14(37.83 \%)$. The odds of having an abnormal pap smear was noted with lower educational status as it showed raise in occurrence of abnormal pap smear findings and in our study low odds (0.123) of abnormal Pap smear is seen with graduate education (table 1).

The number of subjects with age of coitarche (first intercourse) less than 21 years of age was $67(34.54 \%)$ and those more than or equal to 21 years were $127(65.46 \%)$. There were $58(86.56 \%)$ abnormal smears in those under 21 years of age at first intercourse as compared to $42(33.06 \%)$ in those $\geq 21$ years of age at time of coitarche. This difference was proved to be statistically significant with $\mathrm{p}$ value less than 0.05 and the odds ratio was 0.0767 (table 2).

\begin{tabular}{|c|c|c|c|c|c|}
\hline \multirow[t]{2}{*}{$\begin{array}{l}\text { Demographic } \\
\text { characteristics }\end{array}$} & \multicolumn{2}{|c|}{$\begin{array}{l}\text { Normal pap } \\
(\mathrm{n}=94)\end{array}$} & \multicolumn{2}{|c|}{$\begin{array}{l}\text { Abnormal pap } \\
(\mathrm{n}=100)\end{array}$} & \multirow[t]{2}{*}{$\begin{array}{l}\text { P value/ } \\
\text { Odds ratio }\end{array}$} \\
\hline & Number & Percentage & Number & Percentage & \\
\hline Age & & & & & $\mathrm{P}$ value \\
\hline$<20$ yrs $(\mathrm{n}=18) 9.28 \%$ & 7 & $38.88 \%$ & 11 & $61.11 \%$ & \multirow{3}{*}{$\begin{array}{l}0.692196 \\
\text { (Not } \\
\text { significant) }\end{array}$} \\
\hline $20-30$ yrs $(n=126) 64.95 \%$ & 62 & $49.20 \%$ & 64 & $50.79 \%$ & \\
\hline$>30$ yrs $(n=50) 25.77 \%$ & 25 & $50.0 \%$ & 25 & $50.0 \%$ & \\
\hline Residence & & & & & $\mathrm{P}$ value \\
\hline Urban $(n=47) 24.23 \%$ & 33 & $70.21 \%$ & 14 & $29.78 \%$ & \multirow{2}{*}{$\begin{array}{l}0.000606 \\
\text { (significant) }\end{array}$} \\
\hline Rural $(\mathrm{n}=147) 75.77 \%$ & 61 & $41.49 \%$ & 86 & $58.50 \%$ & \\
\hline Socio-economic status & & & & & Odds ratio \\
\hline Upper Middle Class $(\mathrm{n}=19) 9.80 \%$ & 17 & $89.47 \%$ & 2 & $10.52 \%$ & 0.176 \\
\hline Lower Middle Class $(\mathrm{n}=151) 77.84 \%$ & 73 & $48.34 \%$ & 78 & $51.65 \%$ & 15.60 \\
\hline Upper Lower Class $(\mathrm{n}=15) 7.73 \%$ & 3 & $20.0 \%$ & 12 & $80.0 \%$ & 1.33 \\
\hline Lower Class $(n=9) 4.63 \%$ & 1 & $11.1 \%$ & 8 & $88.8 \%$ & 1.143 \\
\hline Education & & & & & Odds ratio \\
\hline Graduate $(\mathrm{n}=37) 19.07 \%$ & 23 & $62.16 \%$ & 14 & $37.83 \%$ & 0.123 \\
\hline Senior secondary $(\mathrm{n}=128) 65.98 \%$ & 63 & $49.21 \%$ & 65 & $50.7 \%$ & 32.50 \\
\hline Middle school $(n=17) 8.76 \%$ & 6 & $35.29 \%$ & 11 & $64.70 \%$ & 2.20 \\
\hline Illiterate $(\mathrm{n}=12) 6.19 \%$ & 2 & $16.66 \%$ & 10 & $83.33 \%$ & 1.250 \\
\hline
\end{tabular}

There were 189 $(97.42 \%)$ subjects with one sexual partner and 5 $(2.58 \%)$ subjects with $>1$ sexual partner. There were $4(80 \%)$ abnormal smears and 1(20\%) normal smear in subjects with $>1$ sexual partner. The frequency of abnormal smear was more in subjects with $>1$ partner in our study, hence it is one of the risk factors (table 2).

As shown in table 2, abnormal smears were $5(83.33 .91 \%)$ in those with history of copper T use, $8(50.0 \%)$ with history of use of oral contraceptives (OCP) and $15(38.46 \%)$ in those using barrier methods. The frequency of abnormal smears among $\mathrm{Cu}-\mathrm{T}$ users was more than other contraceptive methods. 
The New Indian Journal of OBGYN. 2021 (January-June);8(2)

\begin{tabular}{|c|c|c|c|c|c|}
\hline \multirow{2}{*}{$\begin{array}{l}\text { Sexual } \\
\text { history }\end{array}$} & \multicolumn{2}{|c|}{ Normal pap $(n=94)$} & \multicolumn{2}{|c|}{ Abnormal pap (n=100) } & \multirow{2}{*}{$\begin{array}{l}\text { P value/ } \\
\text { Odds ratio }\end{array}$} \\
\hline & Number & Percentage & Number & Percentage & \\
\hline Age at first intercourse & & & & & $\mathrm{p}$ value \\
\hline$<21$ years $(\mathrm{n}=67) 34.54 \%$ & 9 & $13.43 \%$ & 58 & $86.56 \%$ & 0.00001 \\
\hline$>21$ years $(n=127) 65.46 \%$ & 85 & $66.92 \%$ & 42 & $33.07 \%$ & (significant) \\
\hline Number of partners & & & & & $\mathrm{p}$ value \\
\hline $1(\mathrm{n}=189) 97.42 \%$ & 93 & $49.20 \%$ & 96 & $50.79 \%$ & 0.197112 \\
\hline$>1(\mathrm{n}=5) 2.58 \%$ & 1 & $20.0 \%$ & 4 & $80.0 \%$ & (not significant) \\
\hline Contraception & & & & & Odds ratio \\
\hline Barrier methods $(n=40) 20.10 \%$ & 25 & $62.5 \%$ & 15 & $38.46 \%$ & 1.7 \\
\hline OCPs $(n=16) 8.25 \%$ & 8 & $50.0 \%$ & 8 & $50.0 \%$ & 0.93 \\
\hline Copper T $(\mathrm{n}=6) 3.09 \%$ & 1 & $16.66 \%$ & 5 & $83.33 \%$ & 4.9 \\
\hline $\operatorname{Nil}(\mathrm{n}=132) 68.04 \%$ & 60 & $45.45 \%$ & 72 & $54.54 \%$ & 1.5 \\
\hline
\end{tabular}

It was observed that $26 / 85(30.58 \%)$ were abnormal smears in primigravida and 74/104 (67.88\%) abnormal smears in multigravida, hence a greater number of abnormal smears were noted in multigravida which was statistically significant (table 3 ).

In subjects who had previous abortions, out of 20,15 (71.42\%) had abnormal pap smear and 6 (28.57\%) subjects had normal pap smear. The abnormal Pap smear was more in those with previous abortion to those without (table 3 ).

In subjects who had previous preterm delivery $(\mathrm{n}=13)$, abnormal pap smear was seen in $10(76.92 \%)$ while normal pap smear was seen in $3(23.07 \%)$ subjects. The abnormal pap smear was more in those with previous abortion (table 3).

There was 1 participant with history of smoking in our study. We observed, 99 (51.29\%) abnormal smears in nonsmokers and $1(100 \%)$ in smokers but it is a very small sample to generalize the result finding. Here, the $p$ value is

\section{Discussion}

$4(13.79 \%)$ had normal pap smear and $25(86.20 \%)$ had abnormal pap smears. This difference was statistically significant with $\mathrm{p}$ value of less than 0.05 and OR of 7.5 which indicates that the odds of finding unhealthy cervix in an abnormal pap smear was 7.5 times more than that in normal pap smear.

The pap smear test used as a screening method to detect cervical cancer is an effective way to prevent the development of cervical cancer, but awareness within the community about the pap smear test is very low. Pregnancy provides an opportunity for women of a reproductive age to meet an obstetrician and discuss their health concerns and prenatal care offers an excellent opportunity to implement cervical screening in patients of young age.

In our study, the percentage of adequate smears was $97 \%$ which was similar to studies performed by Manikkam et $\mathrm{al}^{17}$, Prabhu TRB et $\mathrm{al}^{18}$. The percentage of smear inadequacy was $3 \%$ which may be due to dryness of the smear or a technical error (improper training of personnel and the use of the improper technique).

The prevalence of abnormal smear in our study is $51.55 \%$. The abnormal smears indicative of inflammatory

\begin{tabular}{|c|c|c|c|c|c|}
\hline \multirow{2}{*}{$\begin{array}{l}\text { Obstetric } \\
\text { history }\end{array}$} & \multicolumn{2}{|c|}{ Normal pap $(n=94)$} & \multicolumn{2}{|c|}{ Abnormal pap $(n=100)$} & \multirow{2}{*}{$\begin{array}{l}P \\
\text { value }\end{array}$} \\
\hline & Number & Percentage & Number & Percentage & \\
\hline \multicolumn{6}{|l|}{ Gravidity } \\
\hline Primigravida $(\mathrm{n}=85) 43.81 \%$ & 59 & $69.41 \%$ & 26 & $30.58 \%$ & \multirow{2}{*}{$\begin{array}{l}0.00001 \\
\text { (significant) }\end{array}$} \\
\hline Multigravida $(\mathrm{n}=109) 56.19 \%$ & 35 & $32.11 \%$ & 74 & $67.88 \%$ & \\
\hline \multicolumn{6}{|l|}{ History of abortion } \\
\hline Yes $(n=21) 10.82 \%$ & 6 & $28.57 \%$ & 15 & $71.42 \%$ & \multirow{2}{*}{$\begin{array}{l}0.053534 \\
\text { (significant) }\end{array}$} \\
\hline No $(n=173) 89.18 \%$ & 88 & $50.86 \%$ & 85 & $49.13 \%$ & \\
\hline \multicolumn{6}{|l|}{ History of pre-term delivery } \\
\hline Yes $(n=13) 6.70 \%$ & 3 & $23.07 \%$ & 10 & $76.92 \%$ & \multirow{2}{*}{$\begin{array}{l}0.05836 \\
\text { (significant) }\end{array}$} \\
\hline No $(n=181) 93.30 \%$ & 91 & $50.27 \%$ & 90 & $49.72 \%$ & \\
\hline
\end{tabular}

smears, bacterial vaginosis, monolial infection, trichomonas vaginalis, ASCUS and LSIL were $29 \%, 9 \%, 7 \%, 3 \%, 1 \%$ and $1 \%$ respectively, whose significance has been a matter of much interest in relation to pregnancy complications. These results were in accordance with Ngaojaruwong $\mathrm{N}$ et $\mathrm{al}^{19}$ who reported the prevalence 0.3 which is not statistically significant.

Out of 70 women with gestational age $<20$ weeks, 28 (40\%) had normal pap smear and $42(60.0 \%)$ had abnormal pap. Among 124 women with gestational age $>20$ weeks, 66 (53.22\%) had normal pap smear and 58 (46.77\%) had abnormal pap smear. We observed that the gestational age had no role to play in occurrence of abnormal pap smear.

Among those with a healthy cervix $(\mathrm{n}=165), 90$ (54.54\%) had normal pap smear and 75 (45.45\%) had abnormal pap smears. And in those with an unhealthy cervix,

of abnormal smears at $38 \%$ in their study, which included smears indicative of candida infections $(23.4 \%)$, bacterial vaginosis $(14 \%)$, trichomonas infection $(0.2 \%)$ and LSIL (0.4\%). Khaengkhor et al ${ }^{20}$ (2011), also reported similar prevalence of abnormal smears at $40.6 \%$ in their study, which included smears indicative of candida infections $(11 \%)$, bacterial vaginosis $(21 \%)$, trichomonas infection $(0.6 \%)$ and LSIL $(3.5 \%)$ and prevalence of these infections was further correlated with premature rupture of membranes (PROM), highlighting their diagnostic importance. 
In contrast, studies like Sueblinvong et al ${ }^{21}$ (2005) had only $9.6 \%$ smears with infections, $0.4 \%$ LSIL and $0.4 \%$ HSIL compared to our study with $1 \%$ LSIL. While in the study conducted by Ghuge et al ${ }^{22}$ the prevalence of bacterial vaginosis was $65.6 \%$ compared to our study of $9 \%$. This emphasizes the importance of regular screening programme during antenatal period, which is in accordance with the American College of Obstetricians (ACOG) guidelines for perinatal care. According to the guidelines, pap smear at first antenatal visit must be taken, if not done prior to pregnancy.

Abnormal pap smears reported in age group of $<20$ years is $61.11 \%$ which was similar to a study done by Himabindu et al ${ }^{23}$. Abnormal smears in age group of 20-30 years accounted for $50.79 \%$ in our study and Bijeta et al ${ }^{24}$ also reported a similar prevalence of abnormal smears in the 20-30 years age group.

Rural population showed more abnormal pap smears in our study. This was in accordance with the study done by Shrestha et al ${ }^{25}$ as well as Arora et al ${ }^{26}$. We note that the correlation of abnormal smears and socioeconomic status was statistically significant $(\mathrm{p}<0.05)$. Thus, socioeconomic status is a risk factor as per our study which is also mentioned in a study done by Seppo Virtanen et al ${ }^{27}$, which shows the impact of socio-economic status on pap smear finding.

$83.33 \%$ among illiterate had abnormal pap smear, among middle school it was $64.70 \%, 50.7 \%$ among senior secondary, $37.83 \%$ among graduates. As the literacy level in Karnataka (rural) is $69.2 \%{ }^{28}$ and in our study $65.9 \%$ among 194 subjects had qualification till senior secondary, abnormal pap smears were comparable with normal pap smears among them. This was in accordance with the study conducted by Shrestha et $\mathrm{al}^{25}$ except for the illiterate population.

$86.56 \% \%$ had abnormal smears among 67 pregnant women who had first intercourse before 21 years. Hence age at first intercourse is one of the risk factors in our study. As in Karnataka mean age for marriage is 20.5 years in total (District Level Household and facility Survey-4, 2012-2013) ${ }^{28}$ and there is early child bearing, hence age of coitarche is less in our study. Mannikam et al (2016) ${ }^{17}$, Sueblinvong et al $(2005)^{21}$, Mohindroo N et al. (2019) ${ }^{30}$ found a similar relation between abnormal smears in pregnant women and early age at first intercourse. Among women with multiple sexual partners, occurrence of abnormal smears was more that is $80 \%$ had abnormal smears which is in accordance with the study done by
Ngaojaruwong $\mathrm{N}$ et al ${ }^{19}$ which shows a link between multiple sexual partners and cervical lesions.

Multigravida account for $30.58 \%$ of abnormal smears, it is one of the risk factor in our study. Manikkam et al $(2016)^{17}$, Prabhu TRB (2016) $)^{18}$, Himabindu et al $(2015)^{23}$ and Bijeta et al $(2015)^{24}$, also reported higher number of abnormal smears in multipara. Hence, screening should take place regardless of gravidity and the first pregnancy is ideal for a first pap smear in an area with no comprehensive screening program.

Our results pertaining to use of contraception showed abnormal smears more in IUCD users, which was similar to study conducted by Mohindroo N et al. ${ }^{30}$ (2019) .Only longterm use of OCPs increases the risk of cervical cancer and the changes caused by OCPs revert to never users after 10 years or more. This suggests that hormonal contraceptives may not increase the risk of cervical neoplasia. There is a need to conduct a cohort study on this topic, to further strengthen or refute the safety of hormonal contraceptives. ${ }^{31,32}$

The percentage of smokers in our study was $0.52 \%$ which is similar to study done by Mohindroo $\mathrm{N}$ et al. (2019) ${ }^{30}$ which shows $0.9 \%$, but in the study conducted by Ngaojaruwong et al (2008) it was 6.8\%, lower incidence could be because women in the studied population smoke less or were not forthcoming in history. We did not find significant relation between history of smoking and abnormal smears. This was not in accordance with the study done by Ngaojaruwong et $\mathrm{al}^{19}$, which shows a link between smoking and abnormal cervical smears.

Abnormal smears were reported more in women with unhealthy cervix $(\mathrm{p}=0.000051)$ which is similar to a study conducted by Himabindhu et $\mathrm{al}^{23}$ and Mohindroo $\mathrm{N}$ et al. $(2019)^{30}$. On per speculum examination, if cervix is found to be unhealthly, it is considered as an independent risk factor per se for abnormal smear and cervical pathology.

\section{Conclusion}

This study highlights the risk factors associated with abnormal smears and particularly those patients must be counseled, educated and followed up to prevent the progression to invasive cancer. In order to reduce the burden of cervical cancer in developing country where the medical services are sparse in rural areas, pregnant women seeking obstetricians for regular antenatal visit must be screened for possible pre invasive lesion of cervix, this opportunity must not be missed (opportunistic screening). Pap smear test is easy to perform, cost effective and doesn't affect the course 
The New Indian Journal of OBGYN. 2021 (January-June);8(2)

of pregnancy and hence, plays a major role in decreasing this preventable disease.

\section{Conflict of interest: None. Disclaimer: Nil.}

\section{References}

1. Denny L. Cervical cancer: prevention and treatment. Discov Med. 2012; 14:125-31.

2. Arbyn M, Weiderpass E, Bruni L, de Sanjosé S, Saraiya M, Ferlay J, et al. Estimates of incidence and mortality of cervical cancer in 2018: A worldwide analysis. Lancet Glob Health. 2020; 8: e191-203.

3. Accuracy of visual screening for cervical neoplasia: results from an IARC multicentre study in India and Africa. International Journal of Cancer, 2004; 110: 907- 13.

4. World Health Organization. The global burden of disease: 2004 update. Geneva: World Health Organization; 2008. Available from: https://apps.who. int/iris/ handle/10665/43942.

5. Satija A. Cervical Cancer in India. South Asia Centre for Chronic Disease. Available from: http://www.sancd.org /uploads/pdf/cervical_cancer.pdf. [Last accessed on 2018 Sept 12].

6. Mathew A, George PS. Trends in incidence and mortality rates of squamous cell carcinoma and adenocarcinoma of cervix- worldwide. Asian Pac J Cancer Prev. 2009; 10: 645-50.

7. American Cancer Society. Cancer Facts and Figures 2018. Atlanta: American Cancer Society; 2018.

8. Drew PA, Wilkinson EJ. Conventional cytology. In: Apgar BS, Brotzman GL, Spitzer M, editors. Colposcopy principles and practice, An integrated textbook and Atlas. 2nd ed. Philadelphia PA: Saunders Elsevier; 2008. pp.59-5.

9. Bergström R, Sparén P, Adami HO. Trends in the cancer of the cervix uteri. Br J Cancer. 1999; 81:159-66.

10. Morice P, Uzan C, Gouy S, Versharaegen C, HaieMeder C. Gynaecological cancers in pregnancy. Lancet. 2012; 379: 558-69.

11. Ferenczy A, Franco E. Cervical-cancer screening beyond the year 2000. Lancet Oncol. 20012:27-32.

12. Nelson DB, Bellamy S, Nachamkin I, Ruffin A, AllenTaylor L, Friedenberg FK. Characteristics and pregnancy outcomes of pregnant women asymptomatic for bacterial vaginosis. Matern Child Health J. 2008; 12: $216-22$.
13. Shrestha S, Tuladhar NR, Basnyat S, Acharya GP,Shrestha P, Kumar P. Prevalence of vaginitis among pregnant women attending Paropakar Maternity and Women's Hospital, Thapathali, Kathmandu, Nepal. Nepal Med Coll J. 2011; 13:293-96.

14. Hay PE, Lamont RF, Taylor-Robinson D, Morgan DJ, Ison $\mathrm{C}$, Pearson J. Abnormal bacterial colonization of the genital tract and subsequent preterm delivery and late miscarriage. B M J. 1994; 308: 295.

15. Misra V, Dorairajan G, Neelaiah S, Chinnakali P. Int J Reprod Contracept Obstet Gynecol. 2015; 4(5): $1296-99$.

16. Hong JN, Berggren EK, Campbell SL, Smith JS, Rahangdale L. Abnormal cervical cancer screening in pregnancy and preterm delivery. Paediatr Perinat Epidemiol. 2014 Jul; 28(4): 297-301.

17. Manikkam B. Screening for cervical cancer during pregnancy. Int J Community Med Public Health. 2016 Sep; 3(9):2493-98.

18. Prabhu T RB, Velayudham D, Nethaji S, Singhal H, Venkatachalam R. Opportunistic Cervical Cancer Screening in Pregnancy. Int $\mathrm{J}$ Med Res Health Sci. 2016; 5(1): 278-81.

19. Ngaojaruwong N, Vuthiwong C, Punpuckdeekoon P, Thongsorn N. Prevalence of abnormal Papanicolaou smear in pregnant women at Phramongkutklao Hospital. Thai J Obstet Gynaecol. 2008; 16:179-85.

20. Khaengkhor P, Mairaing K, Suwannarurk K, Thaweekul Y, Poomtavorn Y, Pattaraarchachai J, et al. Prevalence of abnormal cervical cytology by liquid based cytology in the antenatal care clinic, Thammasat University Hospital. J Med Assoc Thai. 2011; 94:152-8.

21. Sueblinvong T1, Suwannarurk K, Chanthasenanont A, Treetampinich C, Pongrojpaw D. Prevalance and management of Abnormal Pap smear in antenatal care clinic at Thammasat University Hospital. J Med Assoc Thai. 2005; 88(2) 133-7.

22. Ghuge P, Gopalghare D. Prevalence of bacterial vaginosis in pregnancy after 20 weeks of gestation. J. Evolution Med. Dent. Sci. 2017; 6 (84):5841-84.

23. Himabindu P, Kanwal A, Vasudha. Pap Smear In Antenatal Women - Routine Screening In Low Resource Setting. Int Org Sci Res J Dent Med Sci (IOSR-JDMS). 2015; 14(3): 4-5.

24. Bijeta, Singh S. Incidence of bacterial vaginosis in patients with idiopathic preterm labour. Int J Reprod Contracept Obstet Gynecol. 2015 Jun; 4(3): 641-46. 
The New Indian Journal of OBGYN. 2021 (January-June);8(2)

25. Shrestha S, Tuladhar NR, Basnyat S, Acharya GP,Shrestha P, Kumar P. Prevalence of vaginitis among pregnant women attending Paropakar Maternity and Women's Hospital, Thapathali, Kathmandu, Nepal. Nepal Med Coll J. 2011; 13: 293-96.

26. Arora BB, Maheshwari M, Devgan N, Arora DR. Prevalence of Trichomoniasis, Vaginal Candidiasis, Genital Herpes, Chlamydiasis, and Actinomycosis among Urban and Rural Women of Haryana, India. J Sex Transm Dis. 2014; 2014: 963812.

27. Virtanen S, Rantsi T, Virtanen A, Kervinen K, Nieminen P, Kalliala I, et al. Vaginal Microbiota Composition Correlates Between Pap Smear Microscopy and Next Generation Sequencing and Associates to Socioeconomic Status. Sci Rep. 2019 May 23; 9(1): 7750.

28. District Level Household and Facility Survey -4, State Fact Sheet Karnataka (2012-13), Ministry of Health and Family Welfare. Available from: http://rchiips.org/ pdf/dlhs4/ report/KA.pdf.

29. Manikkam B. Screening for cervical cancer during pregnancy. Int J Community Med Public Health. 2016 Sep; 3(9):2493-98.
30. Mohindroo N, Sharma A, Minhas S, Pathania K Prevalence and associated risk factors of abnormal pap smear in pregnant women. Int $\mathrm{J}$ Reprod Contracept Obstet Gynecol. 2019; 8: 4980-4.

31. Misra V, Dorairajan G, Neelaiah S, Chinnakali P. Int J Reprod Contracept Obstet Gynecol. 2015; 4(5): 1296 - 99.

32. He Y, Wu YM, Wang T, Song F, Wang Y, Zhu L. Perinatal outcomes of pregnant women with cervical intraepithelial neoplasia. Arch Gynecol Obstet. 2013; 288:1237-42.

Niyaf $\mathrm{NA}^{1}$, Bhavya $\mathrm{HU}^{2}$, Ravikanth $\mathrm{GO}^{3}$, Geeta J Doppa ${ }^{4}$ ${ }^{1}$ Junior Resident, Dept of Obstetrics \& Gynecology, KVG Medical college \& Hospital, Sullia, Karnataka, India; ${ }^{2}$ Associate Professor, Dept of Obstetrics \& Gynecology, KVG Medical college \& Hospital, Sullia, Karnataka, India; ${ }^{3}$ Associate Professor, Dept of Obstetrics \& Gynecology, KVG Medical college \& Hospital, Sullia, Karnataka, India; ${ }^{4}$ Professor and Head, Dept of Obstetrics \& Gynecology, KVG Medical college \& Hospital, Sullia, India. 